bose. Hun ble gitt warfarin som planlegges brukt i minst to år før ny hematologisk vurdering.

Seks dager før innleggelsen merket pasienten en påfallende dyspné. Symptomene forverret seg dagen før innleggelse, og hun hadde planlagt å gå til lege.

$\mathrm{Vi}$ antar at bruk av p-piller bidro vesentlig til den aktuelle tromboemboliske hendelsen. Orale prevensjonsmidler øker risiko for tromboembolisk sykdom som øker ytterligere ved samtidig koagulasjonsforstyrrelse.

Pasienten har gitt samtykke til at artikkelen blir publisert.

Oppgitte interessekonflikter: Ingen
Litteratur

. Aklog L, Williams CS, Byrne JG et al. Acute pulmonary embolectomy: a contemporary approach. Circulation 2002; 105: 1416-9.

2. Jansen BF, red. Felleskatalogen. Oslo: Fagbokforlaget, 2009: 708 .

3. Parissis JT, Paraskevaidis I, Bistola V et al. Effects of Levosimendan on right ventricular function in patients with advanced heart failure. Am J Cardiol 2006: 98: 1489-92.

4. Task force for the diagnosis and managemen of acute pulmonary embolism of the European Society of Cardiology. Guidelines on diagnosis and management of acute pulmonary embolism. Eur Heart J 2008: 29: 2276-315

5. Lohan DG, Cronin CG, Meehan CP et al. Massive pulmonary embolus with hemodynamic compromise: therapeutic options. Emerg Radiol 2007: 13: $161-9$

6. Chou T. Electrocardiography in clinical practice. 2. utg. Orlando, FL: Grune \& Stratton, 1986 $309-17$.

7. Stulz P, Schläpfer R, Feer R et al. Decision making in the surgical treatment of massive pulmonary embolism Eur J Cardiothorac Surg 1994: 8 : 188-93.

8. Dauphine C, Omari B. Pulmonary embolectomy for acute massive pulmonary embolism. Ann Thorac Surg 2005; 79: $1240-4$

9. Konstantinides S, Geibel A, Heusel G et al. Heparin plus alteplase compared with heparin alone in patients with submassive pulmonary embolism. N Engl J Med 2002; 347: 1143-50.

10. Verstaete M, Miller GA, Bounameaux $\mathrm{H}$ et al. Intravenous and intrapulmonary recombinant tissue type plasminogen activator in the treatment of acute massive pulmonary embolism. Circulation 1988: 77: 353-60.

11. Meneveau N, Seronde MF, Blonde MC et al. Management of unsuccessful thrombolysis in acute massive pulmonary embolism. Chest. 2006; 129: $1043-50$

Manuskriptet ble mottatt 25.11. 2008 og godkjent 27.8. 2009. Medisinsk redaktør Odd Terje Brustugun.

\title{
Kommentar
}

\section{Nærhet til en hjerte-lunge-maskin}

Kardiogent sjokk betinget i massiv lungeemboli medfører høy mortalitet. Tilstanden kan reverseres ved rask diagnostikk og behandling. Dette demonstreres klart av Petter Vanke og medarbeidere, som ved hjelp av åpen pulmonal embolektomi lyktes $\mathrm{i}$ å bringe en 20-årig kvinne fra hjertestans til full restitusjon. En avgjørende suksessfaktor var nærhet til en hjerte-lunge-maskin. Idet pasienten kollapset sirkulatorisk for tredje gang, overtok en mekanisk pumpe og en oksygenator for det sviktende hjertet. Hun ble derved sikret oksygenering og sirkulasjon inntil obstruksjonen av de sentrale lungekarene var hevet kirurgisk og hjerte- og lungefunksjonen gjenopprettet.

De kardiopulmonale kompensasjonsmekanismene er utilstrekkelige ved en akutt tromboembolisk obstruksjon av mer enn $50 \%$ av lungekarsengen. Den umiddelbare økningen av arterietrykket (afterload) medfører høyere veggtensjon i høyre ventrikkel, som dilaterer og svikter. Høyre ventrikkels reduserte ytelse begrenser fyllingen av venstre ventrikkel slik at minuttvolumet faller også i systemkretsløpet. Respirasjonssvikt kan inntre sekundært til de hemodynamiske forstyrrelsene. Et fatalt forløp skyldes i de fleste tilfeller akutt eller progredierende høyre ventrikkel-svikt $(1,2)$.

De fleste dødsfall ved lungeemboli inntrer kort etter symptomdebut (2). Man må derfor raskt ta stilling til om man vil gi trombolytisk behandling i tillegg til antikoagulasjon. Hos pasienter med høy risiko for umiddelbar død anbefales trombolytisk behandling, administrert enten systemisk eller via kateter direkte i lungekretsløpet (1-3). I risikovurderingen vektlegges særlig graden av sirkulasjonssvikt, høyre ventrikkel-dys- funksjon og utslipp av myokardmarkører. Trombolytisk behandling akselererer oppløsning av trombene, fremmer normalisering av høyre ventrikkels pumpefunksjon og bedrer etter alt å dømme overlevelsen hos høyrisikopasienter. Trombolytisk behandling øker imidlertid risikoen for fatale blødninger og invalidiserende apopleksi $(1,3)$.

Forutsatt tilgang på hjertekirurgisk service må embolektomi vurderes når farmakologisk trombolyse har mislyktes eller er forbundet med uakseptabel blødningsfare. Inngrepet er aktuelt også for pasienter under pågående resuscitering, når trombolytika ikke kan forventes å virke tilstrekkelig raskt, og når det finnes tilleggsindikasjon for umiddelbar hjertekirurgi (f.eks. lukning av foramen ovale) $(1,3)$. Inngrepet utføres med støtte av hjerte-lunge-maskin, i normotermi og som regel uten at hjertet stanses. Truncus pulmonalis åpnes og tromboembolisk materiale evakueres $(1,3)$.

Hjerte-lunge-maskinen er ikke forbeholdt operasjonsstuen, men kan også fylle en fremskutt rolle i behandlingskjeden. Pasienter i kardiogent sjokk forårsaket av lungeemboli, hjerteinfarkt eller myokarditt kan i akuttmottaket, i løpet av få minutter etter innleggelse og under pågående resuscitering tilkobles en transportabel ekstrakorporal membranoksygenerings- (ECMO)-enhet via perkutane kanyler i femoralkarene. Man oppnår derved effektiv oksygenering og organperfusjon samt umiddelbar avlastning av hjertet mens pasienten gjennomgår diagnostikk og etter hvert definitiv behandling. I en nylig publisert multisenterstudie kunne 79 av 295 pasienter ( $27 \%$ ) skrives ut i live etter ECMO-støttet resuscitering (4). Mer utstrakt bruk av dette behandlingsprinsippet i Norge imøteses.
Oppgitte interessekonflikter: Ingen

\section{Kristian Bartnes}

kristian.bartnes@unn.no

Hjerte-, lunge- og karkirurgisk avdeling

Universitetssykehuset Nord-Norge

9038 Tromsø

\section{Litteratur}

1. Torbicki A, Perrier A, Konstantinides $\mathrm{S}$ et al. Guidelines on the diagnosis and management of acute pulmonary embolism. Eur Heart J 2008; 29 : $2276-315$

2. Tapson VF. Acute pulmonary embolism. N Engl J Med 2008; 358: 1037-52.

3. Kearon C, Kahn SR, Agnelli G et al. Antithrombotic therapy for venous thromboembolic disease. American College of Chest Physicians evidence based clinical practice guidelines (8th Edition). Chest 2008; 133 (suppl): 454-545.

4. Thiagarajan RR, Brogan TV, Scheurer MA et al. Extracorporeal membrane oxygenation to support cardiopulmonary resuscitation in adults. Ann Thorac Surg 2009; 87: 778-85

Manuskriptet ble mottatt 30.9. 2009 og godkjent 15.10. 2009. Medisinsk redaktør Odd Terje Brustugun. 